\title{
A Maximal Understanding of Sacrifice: Bataille, Richard Wagner, Pilgrimage and the Bayreuth Festival
}

\author{
Philip Smith ${ }^{1, *}$ and Florian Stoll ${ }^{2, *}$ (D) \\ 1 Department of Sociology, Yale University, New Haven, CT 06511, USA \\ 2 Research Center Global Dynamics (Recent Globe), Leipzig University, Strohsackpassage, Nikolaistr. 6-10, \\ 04109 Leipzig, Germany \\ * Correspondence: philip.smith@yale.edu (P.S.); florian.stoll@uni-leipzig.de (F.S.)
}

check for

updates

Citation: Smith, Philip, and Florian Stoll. 2021. A Maximal

Understanding of Sacrifice: Bataille, Richard Wagner, Pilgrimage and the Bayreuth Festival. Religions 12: 48. https://doi.org/10.3390/rel12010048

Received: 20 December 2020

Accepted: 7 January 2021

Published: 11 January 2021

Publisher's Note: MDPI stays neutral with regard to jurisdictional clai$\mathrm{ms}$ in published maps and institutional affiliations.

Copyright: (C) 2021 by the authors. Licensee MDPI, Basel, Switzerland. This article is an open access article distributed under the terms and conditions of the Creative Commons Attribution (CC BY) license (https:// creativecommons.org/licenses/by/ $4.0 /)$.

\begin{abstract}
This paper calls for a broad conception of sacrifice to be developed as a resource for cultural sociology. It argues the term was framed too narrowly in the classical work of Hubert and Mauss. The later approach of Bataille permits a maximal understanding of sacrifice as non-utilitarian expenditures of money, energy, passion and effort directed towards the experience of transcendence. From this perspective, pilgrimage can be understood as a specific modality of sacrificial activity. This paper applies this understanding of sacrifice and pilgrimage to the annual Bayreuth "Wagner" Festival in Germany. Drawing on a multi-year mixed-methods study involving ethnography, semistructured interviews and historical research, the article traces sacrificial expenditures at the level of individual festival attendees. These include financial costs, arduous travel, dedicated research of the artworks, and disciplines of the body. Some are lucky enough to experience transcendence in the form of deep emotional experience, and a sense of contact with sacred spaces and forces. Our study is intended as an exemplary paradigm case that can be drawn upon analogically by scholars. We suggest that other aspects of social experience, including many that are more 'everyday', can be understood through a maximal model of sacrifice and that a rigorous, wider comparative sociology could be developed using this tool.
\end{abstract}

Keywords: sacrifice; pilgrimage; sacred; festivals; Wagner; Bayreuth; Durkheim; opera

Narrowly understood sacrifice conjures the image of priests, shamans, altars, dead animals and burnt offerings-in short religious contexts and certain forms of institutionalized ritual. However, in this paper, we argue that a fluid and 'maximal' understanding of sacrifice is more useful for social science. Sacrifice can be understood as those irrational, evanescent expenditures-of money, time, energy, goods, concern, passion, attention, discipline-in life that generate the experience of a more meaningful personal and collective existence, and, at the limit, an encounter with the sacred. Of course, the experiences and their attendant sacrifices will be of varying intensity and take diverse forms in particular lifeworlds, settings and social contexts. These require specification, and such is the task for the sociologist seeking to make the general model tractable as a way of seeing. We illustrate all this with reference to the composer Richard Wagner's Bayreuth Festival, a major cultural event that takes place every summer in Germany. We demonstrate that a maximal theory of sacrifice helps us understand this particular gathering, along with its participant motivations, experiences and patterns of action. We also show that it belongs to the specific sacrifice modality of 'pilgrimage'. This has its own dynamics and needs to be understood from within as a form of life. To make sense of our approach and what it contributes, we need first to detour into the history of cultural theory.

Within the Durkheimian tradition, the canonical resource for understanding sacrifice is the one-hundred-and-nine-page essay by Henri Hubert and Marcel Mauss, first published in the Année Sociologique in 1899. It had taken several months to write-longer than expected despite the persistent urgings and micro-management of Émile Durkheim himself. Under the auspices of E.E. Evans-Pritchard, the item was eventually translated into English as 
many as six decades later and published as a small book (Hubert and Mauss 1964). The venture was driven more by intellectual devotion than by popular demand in the academic community. The Foreword by Evans-Pritchard notes and accounts for neglect: "If little reference to this Essay has been made in recent decades it is perhaps due to a lack of interest among sociologists and anthropologists in religion and therefore its most fundamental rite" (Evans-Pritchard 1964, p. viii).

Does this statement hold true today? In one way, no. Since the late-1980s, cultural sociology, to take just one intellectual field, has drawn heavily on the Elementary Forms of Religious Life (Durkheim 1995) to develop a comprehensive understanding not so much of religion but rather of the wider 'religious' dimensions of society (Smith 2020). According to the Strong Program, for example, the world is classified into the sacred and profane (Alexander and Smith 2010); and for Collins (2004), social structure consists of nested and contending interaction rituals that generate totemic power. But if the religious/ritual quality of social life has moved center stage, it is not clear that Hubert and Mauss's essay has garnered that much interest as a consequence. At the time of writing, there are a little over 2000 citations listed on Google Scholar for all versions of this 'classic' and, following through, we find that many of those are in the history of theory mode. The short book is often noted but less frequently used. Why so?

At the heart of the limited appeal is the narrow understanding in Essai sur la Nature et la Fonction du Sacrifice. 'Sacrifice' here is not a particularly useful, supple or general concept. For all their pioneering brilliance, Hubert and Mauss were still attempting to intervene in the anthropological debates of the late-Victorian era that had been set in motion by Tylor and Frazer, and above all Robertson Smith. In his Religion of the Semites, Robertson Smith (2002) argued that the origins of sacrifice lay in totemism, and notably the collective meal during which the tribe generated a sense of common identity through consumption of the totemic animal. With the emergence of agriculture, the domestication of animals and increases in social complexity, the feast had been replaced with an expiatory sacrifice that was mediated, symbolic or tokenistic in form and guided by priestly specialists. True enough, Hubert and Mauss fault Robertson Smith's method and his speculative efforts at a reconstruction of the evolution of a complex social and cultural institution. And to their credit, in its place, they offer a more universal or structural vision of the necessary and functional elements of a sacrificial system. Yet as they trawl through examples from Vedic, Christian, Greek, Babylonian and Egyptian civilizations in a virtuoso display of ethnological encyclopedism, the image remains one of priests and religious devotees killing and destroying upon altars in order to placate Gods or bring about desired social ends. Given the diversity of uses to which the word 'sacrifice' is applied in everyday life, and the later evolution of Durkheimian theory itself, this is a curiously literal/liturgical understanding that does not provide the concept with room to breathe.

Nearly three decades on from his collaboration with Hubert, Marcel Mauss was a more ambitious and fluid thinker. In his celebrated essay on The Gift from 1925, he mapped out a landscape of generalized symbolic flows and non-accumulative exchanges as pivotal to the moral economy of primitive society (Mauss 1954). Whereas modern capitalism was marked in his view by utilitarian calculation, commodities, and profit seeking, these gift economies involved generosity, reciprocity, and the sharing and destruction of surplus goods. Pivotal to Mauss arriving at this point of insight was an impactful reading of the work of Bronislaw Malinowski. In his masterwork Argonauts of the Western Pacific, first published three years before The Gift in 1922, Malinowski (1932) offered a vivid description and analysis of the kula ring. This saw venerated ceremonial objects, such as shell jewelry, circulate around remote islands in a process that involved risky open canoe voyages over hundreds of kilometers, followed by elaborate ceremonies of welcome and exchange. The recipients of the artefacts were obligated to pass them on. They could not hoard, nor sell the valuable items for profit. Argonauts emphasized that kula exchange was clearly differentiated from the market exchange in the Trobriand Islands that was known as gimwali. This involved more conventional understandings of pricing, fungibility and commensurability. 
Although kula exchange appeared irrational in terms of any risk/energy/reward calculus Malinowski, in his trademark effort to foreground primitive rationality, stressed the benefits to the individual of being a central player in kula exchange networks. In receiving and giving away goods, they gained social visibility and prestige. Mauss, ever the Durkheimian, differed in seeing kula exchange as an act that was more about collectivities than the desires of individuals and the politics of village life. It tied entire societies together, prevented war and was about solidarity and shared ritual experience.

So Mauss perceived a deep, binding sociality arising from the movement of sacred items around the kula ring of Melanesia and drew parallels with another constitutive social fact that had seized the attention of ethnologists-the wholesale destruction of trade goods in the potlatch of the tribes of the Pacific Northwest. Yet he never quite connected his thinking in The Gift to his earlier work with Hubert via an adequate discussion of how sacrifice could be seen as imminent to such aspects of ritualized, solidaristic economicsocial activity. Symptomatic of this was the fact that whereas gift exchange was broadly understood as moral and communicative, potlatch was viewed with a hint of suspicion as a competitive activity_ironically a reading not unlike that which Malinowski had made of the kula ring. There was a certain asymmetry to the evaluation that prevented Mauss from seeing positive dimensions to destruction/consumption/waste as well as exchange and sharing. Furthermore, Mauss had folded in a critique of modernity into his description of the gift economy. His normatively loaded examples suggested that it mostly belonged in the simple and wise societies of the past. Mauss had painted himself into the ethnologist's corner. How, then, could the lessons from The Gift be deployed to understand modernity?

It was to be the maverick Durkheimian Bataille $(1985,1988)$ who joined the dots in the two decades following the publication of Mauss's essay. He did so in three important ways. First, he explicitly connected Mauss's work on primitive economics to the theme of sacrifice, suggesting that all operations of consumption have a sacrificial logic. They are the forms of destruction and expenditure that curiously enough hold society together. Secondly, he insisted that modern society also had the primitive economic operations Mauss had identified and that sacred forces were behind these. Whereas Mauss had ghosted in a critique of modernity, Bataille thought that we were not particularly modern. Thirdly, Bataille offers a more general resource and set of examples that drag the study of 'sacrifice' away from its theological origins and so expand the concept's explanatory reach to explain a raft of activities and passions. The consequence? Bataille was able to consider a large proportion of the modern political economy to be founded on logics of sacrifice.

Drawing on Mauss on gift economies, Durkheim (1995) on the ambivalence of the sacred and Hertz (1960) on the bilateral symbolism of left and right, as well as upon surrealism, Freud and a general distrust of Western civilization, Bataille developed a complex and somewhat cosmological vision of cultural life. Energy pours into the planet from the sun. This surplus energy leads to the production of life forms. Human cultures feed off these, developing complex symbolic systems and patterns of association. Cosmological balance can only be restored when that surplus is destroyed. In Bataille's vision, the core of sociality lay in these irrational expenditures of a sacrificial nature that enabled a flow and translation of energies. But he did not see 'sacrifice' in the narrow way of Robertson Smith, or Hubert and Mauss. Rather, Bataille opens up a landscape that includes acts of violence, eroticism and desire, individual efforts towards the experience of sacred terror, the love of luxury, and the sybaritic pleasures of indulgence and decadence. All these were essentially non-utilitarian, ceremonial activities that fruitfully disposed of surplus capital and energy rather than engaging in rational, profane accumulation. Through these expenditures, social life was valorized, completed and made whole. It is no accident that in his masterwork of the 1940s The Accursed Share, Bataille (1988) speaks admiringly and at length of Aztek human sacrifice as a paradigm case. He sees in the complicity of the victims and the extraordinary ceremonial courtesies extended towards them a refined and knowing gesture. The Aztecs, as he saw them, had a deep civilizational awareness of the productive and energizing forces attending to destructive expenditures of human life. 
It is too bad that Bataille's message has never quite stuck, at least in sociology (Smith 2020). He writes in a style that is too literary and elusive, too far from positivism and too full of manifesto-like calls for anarchy. Sociologists in the academy have never quite known what to do with him. Yet the core themes have filtered through to some of the most significant social theory of our time (Riley 2013). Hence, Foucault has written on experiences of the extreme, Baudrillard on consumption rather than production as pivotal to modern capitalism, and Kristeva on the strange attractions of abjection and horror. Perhaps the most influential item attempting to use Bataille in a more conventional mode is Miller's (1998) much cited Theory of Shopping. Based on an ethnography of a north London high street, Miller sees shopping not as a practical activity aimed at provisioning the household but as a series of irrational expenditures that bind society together. It is a vehicle for expressing love, pampering the self, generating ritual solidarity and celebrating social life through a privileging of non-utilitarian, reckless choices that often go against our own better judgement. This is done as much by buying a new shade of lipstick as a pound of potatoes. With the sacrifice of money for that which is not really needed, with the treat, gift, or upsell come emotional and spiritual rewards that affirm and build human relationships.

But shopping is just one domain where the sacrifice/expenditure model holds. Consider the following grist for Bataille's all-purpose mill: Formula One motorsport; high fashion and fast fashion; New Year firework displays; Roller Derby; the bullfight; boxing; hobbies that soak up discretionary income; risky sex with strangers; gift giving in the family; getting drunk on Friday night; women's overpriced haircuts and hair styling; super yachts or the much smaller boat that stretches the family budget; the circus; carnival; meticulously white sneakers in poor neighborhoods; funerals; Las Vegas; collecting garden gnomes. As the saying goes, the possibilities are endless. And note that each of these domains of irrational expenditure and theaters of excess has its own rules of the game, its own emotional rewards, subject positions, performative scripts and cultural codes. So the general vision of sacrifice needs to be specified through detailed sociological inquiry into defined spheres of activity in particular lifeworlds. Bataille's model points to a general direction of intellectual travel, but it is just too imprecise to do the detailed explanatory mapping of empirical sociology. Rather, we need blueprints for the geometries of specific irrational expenditures. To illustrate the point, our paper applies the general thematic of sacrifice and expenditure to the specificities of Wagner fans at the Bayreuth Festival. It considers the search for aesthetic pleasure and the role of travel. In so doing, we make use of a developed intermediary resource in the cultural sociological toolbox-the concept of pilgrimage. This brings the gloss of 'sacrifice' down to earth in a middle range way. Now to our second detour into theory.

\section{Pilgrimage}

Within the Durkheimian tradition, the classical resource for understanding pilgrimage is far less well known than the Hubert and Mauss essay on sacrifice. Indeed, less than thirty years ago, Macclancy (1994, p. 32) noted in a review essay that he could find only one reference to it in the English literature and that it seemed unknown even to most pilgrimage specialists. The first English translation was not until the 1980s and even then it was not easy to find, buried he tells us in an edited collection. The item in question Saint Besse: Etude d'un culte alpestre dealt with pilgrimage to a shrine high in the Alps and was written by Durkheim's talented student Hertz (1913). Published in 1913, it tells how pilgrims came from two different Italian valleys to the shrine carrying a heavy statue, how there was an auction to raise funds, and how pilgrims chipped at rocks so as to have a relic to take home. Hertz recounts competition between cults from the two valleys and their divergent mythologies surrounding the Saint. The approach is somewhat ethnological, 'fact collecting' and theory light. In contrast to Hertz's work on classification and death, the wider lessons have to be extracted by readers. Namely, that in retrospect this is a pioneering study of the politics of ritual and contested collective memory. 
It was, of course, Turner $(1969,1973)$ who much later put pilgrimage firmly on the map for cultural anthropology, sociology and to some extent also religious studies. He saw it as an institutionalized form of liminality. In the course of their journey away from routine social life with its hierarchies and fixed identities, pilgrims would experience an openness to the sacred, the deep solidarity known as 'communitas', and, with this, transformations of the self. Perhaps seeing Durkheim as a functionalist, Turner never recognized that many of his insights were prefigured in Durkheim's (1995) Elementary Forms of Religious Life but the parallels are clear (Smith 2020, p. 183). Importantly, while Hertz opens up the study of pilgrimage to themes of power, Turner comes closer to a more Geertzian understanding of the activity as expressive and meaningful. It exists precisely because it offers symbolic, social and emotional rewards. Like 'sacrifice', however, 'pilgrimage' was been hamstrung over the years by narrow applications to religious contexts-such as travel to Jerusalem, Mecca and saintly shrines in Spain, Latin America or India. It is through wider literatures such as tourism studies that we first started to see a broader range of activities through this lens. Australian backpackers travelling to the battlefields of Gallipoli in Turkey, for example, are encountering sacred national myths in a very personal, emotive and embodied way (West 2008). Their extended vacation is reasonably viewed as a pilgrimage, or at least of having pilgrimage-like properties during some phases of activity.

Finally, we arrive at the point in this paper where the concepts of 'pilgrimage' and 'sacrifice' can be united. Putting Turner into dialogue with Bataille, we see pilgrimage as a particular lifeworld form of non-rational, 'pointless' expenditure in pursuit of the sacred. Rather than engaging in productive labor and the accumulation of material goods, the pilgrim expends effort and capital as they enter a form of special time to engage in long distance travel, overcome trials and enter into contemplative activity that has no utilitarian purpose. Energy, physical and mental, is discharged freely in celebrating the sacred, deepening the self and generating existentially profound experiences. It is a sacrificial action of a serious kind. Notably pilgrimage requires effort, discipline, asceticism, abstinence and deferred gratification. Many of Bataille's favored illustrations of sacrificial logics involve easy pleasures-alcohol, orgies, luxury goods and bohemian decadence. Pilgrimage alerts us to the ways in which irrational expenditures can take a contrary form while being equally transient, non-utilitarian and non-accumulative. Suffering is a form of sacrifice.

\section{Wagner, Bayreuth and Pilgrimage}

This brings us to the 19th-century composer Richard Wagner and his deeply serious vision of art. Although increasingly indifferent to organized religion and an admirer of the atheist philosopher Schopenhauer, Wagner (1994) nonetheless had a spiritual understanding of social life. He saw art replacing religion as a provider of mythological and spiritual truths and as a source of solace. He also believed in the power of myth, the study of which could provide profound knowledge regarding the centrality of compassion, redemption, suffering, love and sin in meaningful human experience. His own artworks were conceived as bringing listeners closer to this set of understandings at both conscious and unconscious levels. It is no surprise, therefore, to see that themes of pilgrimage and sacrifice loom large in his oeuvre. Characters such as Lohengrin, Siegfried and Parsifal engage in journeys that have spiritual elements and result in trials, transformations, realizations and purifications of the self. As for sacrifice, this is shown to be central to the closure of rupture: Hans Sachs puts aside his desire and renounces his claims on Eva's affections so that the natural order of young love can be restored; Isolde dies so as to bring about a deeply spiritual erotic unity with Tristan and so reconcile 'day' and 'night'; Brünnhilde rejects the cursed Ring des Nibelungen and throws herself on Siegfried's funeral pyre to the sound of the Erlösungs(resolution) motif. We cannot resist noting that these actions within the plot are absolutely consistent with Bataille's logic: sacrifice enables cosmological and social balance to be restored. 
That said, we are not concerned in this paper with the mytho-poetics of Wagner's stage works but rather with his larger social project. In some ways, Wagner can be considered a spiritual social movement leader. He hoped that his final work, Parsifal, "would purify the world by bringing it to a state of Christian pity and renunciation" (Spotts 1994, p. 79). Drawing on the local tradition of community passion plays, he dubbed it a "sacred stage consecration play" (Bühnenweihfestspiel) and for a long time refused permission for it to be performed outside of Bayreuth. Despite the bourgeois tendencies in his personal lifestyle that have long fascinated and disappointed critics (Adorno 2005; Mann 1985), the composer and one-time revolutionary was always something of an egalitarian, ascetic purist when it came to the role of art in society. His theoretical and programmatic writings set out the stall. He despised the ways that opera was subordinated to ostentatious social display in Paris. The opera house he designed at Bayreuth was one in which every seat, deliberately uncomfortable, had a good view of the super-sized stage in a darkened auditorium. Tickets to the first Bayreuth Festival were available at low cost to subscribers who had demonstrated their loyalty to his project, rather than sold off to elites at high prices. His ambition was to develop a rather cult-like cooperative organization, led by himself, organized around the performance of his artworks. The remote location of Bayreuth was also something he praised. In contrast to big cities with their distractions, Bayreuth wasand is-a sleepy country town. Festival-goers would have to make a dedicated trip and, Wagner hoped, would be able to focus on his works seeking therein spiritual truths. There was something stripped back rather than hedonistic about the entire enterprise, despite the complexity and luxuriance of his music. Indeed, attending Bayreuth was conceived by Wagner as something of a pilgrimage: travel to an inconvenient and unfashionable destination, egalitarianism, pursuit of the sacred and self-knowledge were combined. If this was the intent, then what has been the experience?

Since 2015, we have conducted mixed-methods research on the Bayreuth Festival. Central to the project has been the collection of historical accounts, as well as a series of interviews with contemporary festival-goers and substantial ethnographic participation at the event. The accounts and interviews cover a range of topics including the experience of the festival and the town, responses to performances, thoughts about Bayreuth's troubled past due to associations with Hitler and antisemitism, and travel practicalities. Through an investigation of these resources, we can reconstruct the meanings of the event and the ways in which the sacrifice/pilgrimage model keys to this particular context. The themes: travel and movement to a liminal space, suffering and effort, learning and changing the self, egalitarian solidarity, transcendent experience, a sense of the sacred, an awareness of costs and of the activity as deeply meaningful. By attending to these, we come to understand the form of life that is involved in this particular sacrificial domain.

We note in starting that the language of pilgrimage is commonly applied by historians, critics and commentators to the journey to Bayreuth and to capture the mentality of attendees. It is an explicit part of the folk logic, an 'emic' element of Bayreuth-speak and not simply our 'etic' imposition from cultural theory. Hence, commentators make use of the pilgrimage theme to capture ascetic privation and liminality:

"Why content oneself with the annual ritual of the Bavarian Epidaurus, the very architecture of which was designed as an uncomfortable pilgrim's arena to make it easier for the seekers of total aesthetic phenomenon to leave behind the mean comforts of the common world and to raise their minds to the heights of art" (Heller 1985, p. 19)

Or extremes of long-distance travel:

"Although there were fewer foreigners in the audiences during the early years of the century, Bayreuth retained its allure as a place of pilgrimage. The pilgrims came from as far away as China and California" (Spotts 1994, p. 130)

Or self-transformation:

"Does this mean that the former "sanctuary" of the primarily German bourgeoisie is being transformed into an "adventure park" for a post-bourgeois high culture scene, a 
procession to the refuge of eternal truth for a "pilgrimage into the self"?" (Gebhardt and Zingerle 1998, p. 30; our translation)

Our focus here, though, is not so much on the interpretations of other intellectuals, which as we just saw can be laced with irony, and more on the folk logic of participants. How do those coming to Bayreuth view their experiences? What images and stories do they conjure when reflecting on their participation?

Our transcripts and the historical accounts we examined showed that talk about Bayreuth was surprisingly thick with talk about expenditures. These included money, cognitive mental energy and emotions. There is a pervasive sense of effort rather than ease. The efforts are combined with an underlying belief in the significance of the festival and its artworks. Seeing a performance in Bayreuth does not only demand financial spending but also focus, personal dedication and physical discipline. It is crucial to know the dramaturgy, the music and even the German lyrics well to have access to a deeper understanding of Wagner's works. There are no subtitles or translations provided during the performance. Listening to the several-hours-long operas, reading the libretto and even more mundane duties such as organizing tickets and selecting a tuxedo or a festive dress are part of a trip to Bayreuth. All these activities are more than simply 'fun' - they are in fact arduous.

Such expenditures make a visit to Bayreuth a very different experience than ordinary summer travels such as attending the Glastonbury Festival, doing a city trip to Rome, or visiting historical sites in Greece. From Bataille's perspective, of course, these also involve sacrificial 'pointless' expenditures. But with the Festspiele (festival), these expenses and efforts are more visible and intense. It is not a holiday or a cultural event-the logic is one of pilgrimage. And so going to the Festspiele involves a usually complicated trip to the inconveniently located German province, alongside mental and physical preparation to experience spiritual insight-similar to religious pilgrims who walk the Camino de Santiago or go to Mecca. Difficulties and inconveniences are an integral part of the festival. The investments force people to concentrate and so assist in the evolution of passion. In the logic of pilgrimage, the sacrifices involved bring meaning. And that meaning explains why people do not just do the 'sensible thing' and stay at home and watch the operas on DVD. Let us bring in some more detail and go through the sources of effort in a logical order.

\section{Tickets}

We begin with a difficulty that is hiding in plain sight: getting a ticket to a performance. For decades, the major share of tickets was given to clearly defined groups such as the Wagner supporters club Freunde Bayreuths (Friends of Bayreuth) with its expensive membership. Allocations were also made to core players in Germany's industrial and civil order, such as federal employees, trade unions and sponsoring corporations. Wagner's egalitarian dream had failed. The only regular way for opera fans to get tickets was to apply at the festival's dead letter office, then to move up the waiting list year by year. There was much rumor about how to game the inscrutable system. For example, the Munich-based Süddeutsche Zeitung published in 2008 a half-satirical, half-serious article how one can find alternatives to the estimated 10 years waiting time (Zinnecker 2008).

The improbable hunt for tickets demonstrates how the hope for a transcendent experience, waiting and suffering go hand in hand in this case. It is also something that takes the festival in multiple ways out of the exchange system of ordinary commodities and turns participation into something more ritualized and mysterious or providential. The tickets arrive like mana from heaven after long years of frustration. For "Jonathan" (this is a pseudonym and all names in the remainder of this paper have been changed), a 30-year-old Bayreuth-based academic, the annual application adds deep layers of meaning:

"II] found the idea of preparing and fighting for something like this for so long actually very nice. Because where else do you do it? And I always think it's nice that way. [ ... ] You have to apply for it every year anew. Um, in the past it was by post, today it's online and if you forget that, you're out of the game. Then you can start all over again. And that's already part of the ritual, the performance. And I was tempted by the fact that 
there are limits to get it. That you have to do something for it. And this thinking ahead, I find, a period of 7 years, and back then, it was supposed to take 12 or 13 years, that's kind of absurd too. But as I said, I found it attractive. I don't know why exactly" (Our translation from German language interview).

To Jonathan, the ticketing process is a mixture of a thrill about the gamble to get tickets, despair about the low chances and the hope for a unique experience at the opera. It is also an annual "ritual" that once involved mailing letters and now anxiously waiting for the exact moment the online shop opens while repeatedly pressing the 'return' button on a computer keyboard (a nerve-wracking five minutes we replicated during our fieldwork). When Jonathan succeeds with his application, he is extremely happy. His expenditure of energy will bring truly meaningful rewards. Jonathan is lucky-or perhaps, as we will see, unlucky - because he lives in Bayreuth. Most festival visitors need to travel. This is costly financially, costly to family life and costly in terms of energy.

\section{Travel}

For those living overseas, the unpredictability of receiving tickets adds serious organizational problems. It is impossible to plan more than a few months ahead. Carol, a 60-year-old Australian member of a Wagner Society, embodies something close to the maximum of sacrifice in terms of distance travelled, financial efforts relative to income, and disruption to her personal life. On being allocated some tickets, she felt she had no choice but to augment the travel plans to Europe that had already soaked up her carefully budgeted vacation savings.

"We had a trip planned to Ireland and Scotland. And that trip was already organized. And then suddenly here I was with an opportunity to go to Bayreuth. Well so that really made a mess of my trip to Ireland and Scotland. So I'm still going. I'm meeting the girls in Dublin on the 30th of August and so the preparation was crazy. Because suddenly I had to factor in an extra two and a half weeks here with my six tickets to Bayreuth Festival and I had to reorganize my life. And I have a mother and a husband and a daughter and so the preparation the logistical the logistics were just insane. But I'm here. I got here."

Carol demonstrates paradigmatically how highly Wagner fans value a visit to the festival and the extraordinary expenses and inconvenient efforts they are willing to take on themselves and impose on others. Most people would consider a holiday in Ireland and Scotland the experience of a lifetime-enough indulgence for one summer. But Carol does not even think about giving away her tickets. As a former teacher, she has a modest income. Yet she spent thousands on new flights and hotel bookings, extending her trip and causing chaos for her family. As a devotee, what else could she do?

After all the planning, there is the actual 'getting there' that involves moving a body through space. This is a major source of suffering for international travelers especially. Since the 19th-century, attendees have complained about the difficulty of getting to Bayreuth, and notably the poor train service on peculiar branch lines. Bayreuth still has poor connectivity and visitors flying in from abroad usually come via Munich, then Nuremberg, to the festival. Laura, by coincidence another 60-year-old Australian member of a Wagner Society, offers a complaint that became familiar to us concerning the troublesome, multi-connection route from the airport to Bayreuth (something we have experienced more than once during our fieldwork). True to the pilgrimage motif, she told a story of hurdles and challenges arriving one after another and of a body that had to suffer and take risks.

"But last year the flight was into Munich and then I took the train and I did it all in one hit without stopping until I got to Bayreuth. And that involved a train. I'd been on the plane for goodness knows how many hours $24 \mathrm{~h}$ or something and then you get a train a train to the main station in Munich. That worked well. Then I got on a train to Nuremberg and then I had to get off and change platforms to get the train to here. And I had to haul my suitcase. There were no lifts no elevator I had to and I had a bad back. I was not supposed to be doing it. I had to pull my suitcase up the stairs up a really 
long flight of stairs in a rush to get to the train. Fortunately, a young woman helped me. The men don't help you and I got to the train and not enough carriages had turned up. Again you've got the dreadful trains with steps to get your suitcase up. You know it's not sliding you've got to go up and I got to there was no room to even get in the carriage. You had to just stand there. So, on top of twenty four hours in the plane and I'd probably by then had at least two and a half hours or something of trains, three hours maybe. I then had that stand for an hour and it was really stuffy and hot. Just in the stairwell not in the carriages for an hour to get here and that was just dreadful ..."

This is a story of sacrifice in the pilgrimage mode. There is endurance, fatigue, physical effort and even danger to the body.

\section{The Performance}

What could be more relaxing than sitting in a chair listening to opera? Well quite a few things actually. Once you have your tickets, have made it to Bayreuth and up the hill into the concert hall, the economy of effort and suffering does not stop. There is a tax on the body, on the mind, and the soul. In a letter from 1909, the novelist Thomas Mann wrote to a friend about his summer:

"And then I was in Bayreuth for the Parsifal ... But quite apart from the physical exhaustion of it all (it was dreadfully hot), I also found it a demanding emotional experience". (Mann 1985, pp. 44-45)

We find a similar response in the composer Tchaikovsky's (1876) report that although he was a "musician by profession," he was "overcome by a sensation of spiritual and physical fatigue close to utter exhaustion" by the end of Götterdämmerung, the fourth opera in Der Ring des Nibelungen. The Wagnerian George Bernard Shaw was an active young man in the 1880s. Likewise he noted in his dispatches the cognitive labor involved in being a conscientious opera fan and music journalist: "It is desperately hard work this daily scrutiny of the details of an elaborate performance from four to past ten" (Shaw 1889a). The renowned author and critic singled out the particular challenge of the Meistersinger, "I had just energy enough to go home to my bed, instead of lying down on the hillside ... That Third Act, though conducted by Hans Richter, who is no sluggard, lasts two hours, and the strain on the attention, concentrated as it is by the peculiarities of the theater, is enormous" (Shaw 1889b).

What exactly are those 'peculiarities' that troubled Shaw? In contrast to regular concerts, most attendants honor the ritual of the Bayreuth Festival by being dressed in tuxedos or other elegant clothes. These are restrictive and do not permit good ventilation of the body. The central European summer reliably reaches over 30 degrees $C$. The performances are long, the music tempi generally languid. The doors to the auditorium are closed for acoustic purposes. Yet, even today, there is no air conditioning as the building is heritage listed. The heat is trapped. The famously hard seats help somewhat to keep the audience awake, but in their own way they also make focused attention a challenge. This is all something of an ordeal. Peter, a 67-year-old American living in Germany's Heidelberg, is a first-time visitor. He describes his experience in one of the more affordable parts of the concert hall:

Our seats are way up so it's very hot. And people are we're all packed in like sardines up there. So it's not... not comfortable at all but you know you just have to focus.

Peter had done well for a novice-he had translated discomfort into a resource. Yet Helena and Stefanie, two German women aged 70 and 79, underestimated the strain of the long performances, high temperature, and the hard wooden seats. They gave up after the first act due to the unbearable conditions and felt that they could not continue. The trip to Bayreuth was for these ladies a rare opportunity because they were lucky in the online ticket sale. For them, going to Bayreuth was a once-in-a-life-occasion and one of many highculture events that they had attended. But they were not true adepts. Their motivation was more curiosity than a special fascination with Wagner. Unlike more experienced festival 
visitors, these mature-age first-time visitors were not well prepared for the uncomfortable seats and slow performances. They paid a price for it. Stefanie:

In general, I felt good. But the chairs made it hard for me as said before. And then you lose focus. Then I was looking around so much in the theatre to see who is there. You don't notice anymore what is going on onstage. Yes, I was fidgeting a little. There were two girls whispering. Just like us. She [Helena] wanted to tell me something and I had to stop her. It was like that. One loses concentration. One looks left and right to see what others are doing. That's part of it just to stay flexible. Not sitting still. [ . . ] Yes, with other seats we may have fallen asleep but not with these. (Interview in German. Our translation).

Helena and Stefanie were unable to translate discomfort into an incentive to concentrate. Unlike those who had invested heavily-financially, with travel, with bodily effort, with the ritual preparations of studying the artworks-they were unable to interpret the experience as pleasurable or as offering the possibility of encountering transcendence. Viewed through the lens of the Elementary Forms, such draining experiences and privations, forms of disciplinary sacrifice, are perhaps essential as preparations for leaving behind the profane. Hence, Durkheim (1995, p. 314) writes: "no one can engage in a religious ceremony of any importance without first submitting to a sort of initiation". In this context, it is noteworthy that Tchaikovsky (1876), who attended the first iteration of the festival in 1876, considered that his own lack of preparation contributed to a somewhat reserved appreciation of The Ring. He noted that other professional musicians were more enthusiastic than he was before admitting, "I am willing to grant that it is my own fault that I have not yet come to appreciate fully this music, and that, once I have got down to studying it diligently, I too may eventually join the wide circle of genuine admirers of Wagner's music".

\section{Transcendent Experiences}

So attending Bayreuth requires effort and energy. It is draining and uncomfortable. For many, it is expensive. You need to prepare diligently. Expenditures of all kinds abound. But, as both Bataille and Turner argue, at the end of the suffering there can come a connection with sacred spaces and traditions. For example, the reward can be a sense of entering an enchanted land that is separated from profane space. Bayreuth is where the operas that people have been listening to for decades are supposed to be performed-in the building designed by Wagner, built to his specifications, and where the master's eyes personally oversaw the civilizationally significant first productions of the entire Ring (in 1876), and Parsifal (in 1882). For many fans, it is a place that they have read about for years in books about Wagner or the festival, or seen referred to on program notes at other concert halls. In addition to such mystique and mythology, the very travel involved to this annoyingly remote location builds commitment and contributes to a liminal separation from everyday life. A sense of special, slow time can intersect with that of space. Even our German interviewees told us that going to Bayreuth is a very different experience than visiting a performance in their hometowns such as Berlin or Dresden. Instead of rushing to the theater after the office, most festival visitors dedicate the whole day to opera. In the morning, there is often a presentation at the Festspielhaus (the concert hall) that introduces the performance of the afternoon. The day can be spent carefully preparing the mind and body. A study of the libretto is usual. This can be arduous. Alcohol is avoided, food light, an afternoon nap advisable. As in the Aboriginal rituals studied by Durkheim, these smaller preparations, prohibitions and privations are all organized so as to maximize the climactic experience of the artworks over a four-to-eight hour period starting according to Wagner's instruction in the late afternoon.

Several of our interview partners invoked the magic of place, especially during their first visit to Bayreuth. As we just noted, many had spent years reading about Wagner and Bayreuth, or looking at photographs. Encountering them in reality was an intense experience that blurred the lines between myth and reality-not unlike when we encounter 
a celebrity in the street. When asked about this, Preston, a 60-year-old visual artist from the United States, repeated himself as he struggled for words. He spoke in hushed, breathy tones as he mentally recaptured the feeling of an intense sense of otherworldliness he had experienced when he first visited Wagner's own villa, Wahnfried.

Question: What about the fact this is Wagner's town? Does that make it more meaningful?

Preston: Yeah especially in the beginning. I'm just in awe. Every, everywhere you go everything you see is Wagner. It's a magic, magic Kingdom ... This is Wahnfried! This is the dream. The dream.

More important even than Wahnfried as a sacred space was the Festspielhaus. Designed and built by Wagner after considerable financial struggles, it is arguably the largest wooden building in the world. With this all-wood construction, hollow pillars and resonant floors, it has unique acoustics that send vibrations through the body. It seems alive. Some remove their shoes so as to feel this through the soles of their feet. The hall is also famous for the concentration of the audience-known as the "Bayreuth hush". This interactional norm indicating shared devotion also makes the performances special for Preston.

Physically the wood and the sound there's no way in the world anywhere could you build this. I keep forgetting I haven't been here for a couple of years. I started coming in 2001. It's really the orchestra and the sound. Also the concentration of the audience it is pitch black and you're packed, packed in this little place and all you see is the performance and you hear the sound and music.

Another informant, Simon, echoed these feelings about sacred, special places. Simon (German, aged around 50) is today a professional Wagner intellectual and cultural heritage manager. His initial contact with the sacred at Bayreuth came decades ago when he was a student. The visit was literally life changing.

"I remember when I first came to Wahnfried at twenty-one years old when I entered Wahnfried I really walked on the top of my toes. It was something very, very holy like coming to the Holy Grail".

While Bayreuth has sacred places, it is Wagner's music itself that provides a culmination to the pilgrimage quest for the extraordinary. His music has a mesmerizing, deeply emotional effect on many listeners and offers to them a glimpse of transcendence. The impacts can be mysterious and are very hard to explain. Shaw touched upon this theme long ago.

"This Parsifal is a wonderful experience: not a doubt of it. The impression it makes is quite independent of liking the music or understanding the poem... When you leave the theater after your first Parsifal you may not be conscious of having brought away more than a phrase or two of leitmotif ... yet before long the music begins to stir within you and haunt you with growing urgency that in a few days makes another hearing seem a necessity of life". (Shaw 1889c)

Thirty-six years later, Shaw was awarded the Nobel Prize for Literature. So, it is no surprise that our less verbally talented respondents also struggled to explain what was going on. Steffen (German, aged about 60), an accomplished musician, made use of a metaphor we often encountered (and indeed can be found in Nietzsche's writings) — that of bathing in warm water.

"It grabs you by the intellect and grabs you by your feelings and sentiment. Both, right?

You're swimming in beautiful, warm water. "

Sandra [Steffen's wife] added that "My husband can't talk for a long time after such a ... It's, uh ... (Interview in German. Our translation).

This shift towards introversion and silence that Sandra noticed happened to us too. In our field observations, we often noticed that other audience members were unusually quiet as they filed out during intermissions or at the end of the long evening. It seemed as if the music had cast a spell and it would take a while to return to a profane world where words 
were adequate to experience and interactions anything other than a crude intrusion. Like Thomas Mann and Steffen, we and they were emotionally full and emotionally exhausted at the same time. Chat would typically resume as patrons unlocked their cars or passed by the railway station, after about a kilometer on the long, late-night downhill walk back into town.

True to Durkheim's vision of the sacred as a commanding force, Steffen went on to describe the moment of ecstatic submission to the power of the music with reference to the climax in the Third Act of the Meistersinger, where various contending keys that have been at play for the prior four or five hours resolve to $C$ major. The impact on the audience, the vast majority of whom would not be intellectually aware of the compositional technicalities, was such that "it knocks them out. It knocks them out. It brings tears to their eyes or something. They can't breathe."

This sense of meaningful contact with intense emotions and a higher power was also captured by Preston, who contrasted the unique impacts of Wagner to those of other composers. Usually articulate, Preston really struggled to communicate his feelings during our interview.

"I play a lot of Beethoven, Bach, Mozart everything. But with Wagner. He has a knack of taking control of you. Me anyway. His music almost grabbed hold of you and just he could ... manipulate you. And I just, you just totally surrender to Wagner. Other people like Beethoven you play through and there's no emotion, I don't feel any anything inside. With Wagner it's different. And as older when I get older it's even worse you know because ... with Parsifal the music. At one point when the Gurnemanz is singing especially if it is a good bass singing ... and with Wagner's music. I completely lose control ... to tears."

Simon's experience was even more intense. We last encountered him entering Wahnfried on tip-toe. Later that same day, he had slipped into the Festspielhaus and listened to a dress rehearsal of Die Walküre (Valkyrie). His account of what followed was full of the repetitions and expressive struggles we often found in our transcripts when respondents attempted to communicate a sense of the transcendent.

"It was like an infection like a medical infection. I remember after, after Valkyrie I had a spare day, a free day after Valkyrie. I attended the general wh the dress rehearsals and after Valkyrie I had a free day and I took a walk up on the on the Bürgerreuth, this hill behind the Festspielhaus. I climbed up to the Siegesturm, this tower of victory. Yeah I was standing there quite alone for myself and I was in a very, very special mood. It was like everything was floating through me and I was fascinated and really was crying. It was a deep, deep emotional effect. Really it was erotical in a way and very, very special. And well it was like... was ist ein Erweckungserlebnis? An awaking experience. Suddenly something became light in my head. And if it was like like this uh this flash of Erkenntnis, of knowledge, of knowledge. Everything seemed to be clear and I had the impression that I had found something very important for me in my life. Okay. That was the infection and I couldn't stand it anymore."

Simon had indeed encountered the sacred as he looked out over the landscape, the town, fields and rolling wooded hills. There is perfect consistency with Durkheim's observation in the Elementary Forms about the intense experience of a higher power after ritual:

"Its immensity overwhelms him. That sensation of an infinite space surrounding him, of an infinite time preceding and to follow the present moment, of forces infinitely superior to those at his disposal, cannot fail to arouse the idea inside him that there is an infinite power outside him to which he is subject. This idea then enters into our conception of the divine as an essential element." (Durkheim 1995, p. 80)

It is an outcome of which Wagner, no doubt, would have approved. 


\section{Some Closing Thoughts}

We have written about participation in an event that is an impractical, expressive expenditure of surplus, not a rational, accumulative, profitable enterprise. Tchaikovsky (1876) captured this essence when he wrote: "In the sense of contributing to the material prosperity of mankind, the Bayreuth Festival, of course, is of no consequence whatsoever, but in the sense of a quest for the realization of artistic ideals it surely is fated, in some way or other, to acquire a tremendous historical significance". The pilgrimage to Bayreuth is a particular kind of sacrificial activity that attaches to this broader aesthetic project. Suffering, travel to a sacred space, and mental and physical discipline of listening lead in some cases to a transcendent encounter with deeply meaningful complex cultural forms. It is a serious and contemplative mode of expenditure that provides only spiritual rewards. And that is the entire point.

The sacrifice of time, commitment and money is the required expenditure of surplus that makes the trip to Bayreuth a maximal spiritual success. We saw how Wagner fans suffer before and during the events. In some cases, these visitors are completely overwhelmed by attending the operas. The aesthetic experience of the musical theatre, the magic of the place, and restricted access to one of the sought-after performances combine alchemically. The several-hours-long operas, the heat in the Franconian high summer and concentration on the demanding art works distinguish a trip to Bayreuth from fun trips to pop concerts or city breaks. But even as people complain about them, these hurdles are in fact a necessary step towards a more transcendent experience. With the right preparation and mind set, something truly life changing can happen. Within the framework of Bataille's understanding of sacrifice, the impacts of these non-utilitarian costs and privations make perfect sense. As an act of sacrifice built on the hope of grasping transcendence, each of the seemingly irrational acts of spending and restraint brings participants a little closer to their goal. Bataille perfectly sums all this up, not with reference to Europe or modernity but in his understanding of sacrifice among the Aztecs:

"The only valid excess was one that went beyond the bounds, and one whose consumption appeared worthy of the gods. This was the price men paid to escape their downfall and remove the weight introduced in them by the avarice and cold calculation of the real order." (Bataille 1988, p. 60)

The crucial point about human sacrifice for Bataille was that it tore down the established profanity of everyday life and put the individual in immediate contact with the sacred and divine. In its expressive details, an opera in a Bavarian province is not the same as the religious ceremony of an extinct Mexican culture. However, they are analytically akin. Excessive efforts, incommensurability beyond the exchange of equivalents, and the struggle to escape the profane world are the carriers of symbolic and emotional power in both the Aztec event and the German opera festival.

Bataille's brutal case study can be considered a kind of Foucaultian real-world exemplar of a system of ideas and rituals. It highlights by looking to the extreme. In Bayreuth, the cultural patterns are a little more muted and veiled. So of course, there will be a range of experiences and levels of commitment. As we saw with Helena and Stefanie, not everyone going to the opera is an adept or enthusiastic Wagnerian or can be easily interpreted as engaging in pilgrimage activity. For some locals we interviewed, a visit to the Festspielhaus is just another entertaining night out - a lesser form of sacrifice to be sure but for all that an irrational expenditure of efforts just the same. Nor is all tourism to Bayreuth driven by Wagner. Many come to enjoy the beer, the landscape, the flower gardens, and the castles and stately homes that litter the region. And in the everyday life of the town's residents, we might find shopping, drinking, eating, hobby activity, physical training, reading, focused attention, and sex. But are these not also gratuitous expenditures? Understood through the lens used in this paper, we might reconstruct a more comprehensive, nested and layered ecology of the expenditures and sacrifices within the city of Bayreuth, of which the festival and its 'pilgrims' are but a seasonal part. Foucault spoke of a vision of the carceral city, of a network of institutions and activities of control spread out over urban space. With 
a very different dispositif of modernity, a Durkheimian cultural sociology could map out the town's landscape of individual and institutional discipline, effort, sacrifice, emotional and expressive release. To do so would be a magnificent accomplishment, and clearly one that is beyond the scope of this initial inquiry. It is, however, an agenda called forth by the maximal understanding of sacrifice as the expenditure of surplus. Our sketch of the Bayreuth pilgrimage is just an illustration of how one might go about such a task.

Author Contributions: The authors contributed equally to the research and writing of this paper. Both authors have read and agreed to the published version of the manuscript.

Funding: This research was supported by a grant from the MacMillan Center of Yale University and by a University of Bayreuth Centre of International Excellence "Alexander von Humboldt" Senior Fellowship.

Institutional Review Board Statement: This research was conducted according to the Institutional Review Board and informed consent protocols of Yale University and Bayreuth University.

Informed Consent Statement: Informed consent was obtained from all subjects involved in the study.

Data Availability Statement: The authors have all data available. However, the data are subject to restricted access due to confidentiality.

Conflicts of Interest: The authors declare no conflict of interest.

\section{References}

Adorno, Theodor. 2005. In Search of Wagner. London: Verso.

Alexander, Jeffrey, and Philip Smith. 2010. The Strong Program. In Handbook of Cultural Sociology, 2nd ed. Edited by John. R. Hall, Laura Grindstaff and MingCheng Lo. Abingdon: Routledge, pp. 13-24.

Bataille, Georges. 1985. Visions of Excess. Minneapolis: University of Minnesota Press.

Bataille, Georges. 1988. The Accursed Share. New York: Zone Books.

Collins, Randall. 2004. Interaction Ritual Chains. Princeton: Princeton University Press.

Durkheim, Emile. 1995. The Elementary Forms of Religious Life. Translated by K. Fields. New York: Basic Books.

Evans-Pritchard, E. E. 1964. Foreword. In Sacrifice: Its Nature and Function. Edited by Henri Hubert and Marcel Mauss. Translated by W. D. Halls. London: Cohen and West, pp. vii-viii.

Gebhardt, Winfried, and Arnold Zingerle. 1998. Pilgerfahrt ins Ich: Die Bayreuther Richard Wagner-Festspiele und ihr Publikum. Eine kultursoziologische Studie. Konstanz: Universitätsverlag Konstanz.

Heller, Erich. 1985. Introduction. In Thomas Mann Pro- and Contra Wagner Op-Cit. Chicago: University of Chicago Press, pp. 11-22.

Hertz, Robert. 1913. Saint Besse: Etude d'un culte alpestre. Revue de l'Histoire des Religions LXVIII: 115-80.

Hertz, Robert. 1960. Death and the Right Hand. London: Cohen and West.

Hubert, Henri, and Marcel Mauss. 1964. Sacrifice: Its Nature and Function. Translated by W. D. Halls. London: Cohen and West.

Macclancy, Jeremy. 1994. The Construction of Anthropological Genealogies: Robert Hertz, Victor Turner and the Study of Pilgrimage. Journal of the Anthropological Society of Oxford 25: 31-40.

Malinowski, Bronislaw. 1932. Argonauts of the Western Pacific. London: Routledge.

Mann, Thomas. 1985. Pro- and Contra-Wagner. Chicago: University of Chicago Press.

Mauss, Marcel. 1954. The Gift. Translated by I. Cunnison. London: Cohen and West.

Miller, Daniel. 1998. A Theory of Shopping. Cambridge: Polity.

Riley, Alexander T. 2013. Godless Intellectuals. New York: Berghan Books.

Robertson Smith, William. 2002. Religion of the Semites. New Brunswick: Transaction Books.

Shaw, George Bernard. 1889a. Impressions de Voyage. The Star, August 2.

Shaw, George Bernard. 1889b. Bayreuth and Back. The Hawk, August 13.

Shaw, George Bernard. 1889c. The Second Parsifal. The Star, August 7.

Smith, Philip. 2020. Durkheim and After: The Durkheimian Tradition 1893-2020. Cambridge: Polity Press.

Spotts, Frederic. 1994. Bayreuth: A History of the Wagner Festival. New Haven: Yale University Press.

Tchaikovsky, Pyotr Illyich. 1876. The Bayreuth Music Festival. Available online: http://en.tchaikovsky-research.net/pages/The_ Bayreuth_Music_Festival (accessed on 18 December 2020).

Turner, Victor. 1969. The Ritual Process. Chicago: Aldine.

Turner, Victor. 1973. The Center out There: The Pilgrim's Goal. History of Religion 12: 191-230. [CrossRef]

Wagner, Richard. 1994. Religion and Art. Omaha: University of Nebraska Press. 
West, Brad. 2008. Enchanting Pasts. Sociological Theory 26: 258-70. [CrossRef]

Zinnecker, Florian. 2008. Süddeutsche Zeitung Bayreuther Kartentricks. Available online: https://sz-magazin.sueddeutsche.de/ musik/bayreuther-kartentricks-75596 (accessed on 8 August 2020). 